\title{
UNIVERSITY RATING \& DEVELOPMENT: CHALLENGES AND OPPORTUNITIES FOR UKRAINE
}

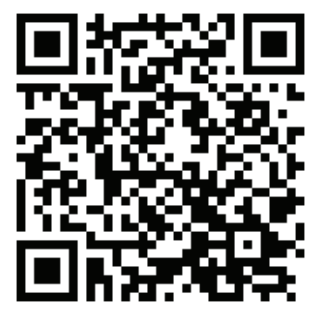

To cite this article:

\author{
Volodymyr Lugovyi, Dr. Sc., Prof. \\ First Vice-President, \\ National Academy of Educational Sciences of Ukraine \\ Kyiv, Ukraine \\ Luhovyi@ukr.net \\ https://orcid.org/0000-0003-1650-066X
}

\author{
Olena Slyusarenko, Dr. Sc., Senior Researcher \\ Vice-Director for Research, \\ Institute of Higher Education, \\ National Academy of Educational Sciences of Ukraine \\ Kyiv, Ukraine \\ Slyusarenko_o@ukr.net \\ https://orcid.org/0000-0001-7957-1794
}

Zhanna Talanova, Dr. Sc., Senior Researcher, Assoc. Prof.

Chief Scientific Officer,

Institute of Higher Education,

National Academy of Educational Sciences of Ukraine,

Analytical Manager,

National Erasmus+ Office in Ukraine

Kyiv, Ukraine

zhanna_t@ukr.net

https://orcid.org/0000-0003-4007-2677

Lugovyi, V., Slyusarenko, O. \& Talanova, Zh. (2019). University

rating \& development: challenges and opportunities for Ukraine.

Education: Modern Discourses, 2, 60-77.

https://doi.org/10.32405/2617-3107-2019-1-8

\begin{abstract}
The article analyzes the long stagnation of the national higher education and estimates its causes and mechanisms of overcoming. According to the criteria of the general and subject versions of the ARWU rating, there are no world-class and subworld-class universities in the country, and there is a lag behind other countries. As ranked by the less objective Times and QS the position of the group of universities has worsened. The Ukrainian network of higher education institutions is quantitatively excessive, qualitatively unsatisfactory. This is due to its repeated duplication, profile inadequacy, fragmentation, institutional weakness. State policy and strategy, contrary to global trends, does not declare the introduction of a national university ranking in the short term. Due to the lack of rating inventory of institutions, society does not clearly identify leading universities and loser universities, suffer from poor higher education, inefficiently spend significant financial and human resources. The priority need for Ukraine to formulate a culture of reliable, objective university rating, the creation of a national rating as a mechanism for assessing the quality of higher education that
\end{abstract}


motivates and mobilizes for continuous institutional improvement, achievement of competitiveness, consolidation of institutions and concentration of resources. It is proposed to launch a national rating of higher education institutions of general, sectoral and regional versions, ranking universities by level of leadership - global, regional, national, subnational, local.

Key words: higher education, quality, accreditation, rating, competitiveness, development, universities, leadership, Ukraine.

\section{INTRODUCTION, PROBLEM STATEMENT}

World globalization and European integration have created new opportunities for the development of higher education through international cooperation and communication. At the same time, university competition for leadership between some institutions, national and regional higher education areas has intensified. In particular, in the face of new challenges, in 1999 Bologna Process for the formation of competitive and attractive European Higher Education Area (EHEA) was initiated in Europe. The formation of the EHEA, the Bologna Process's activities and tools are of interest in other parts of the world, primarily in the competing North American and East Asian Higher Education Areas. This has led to the updating and introduction of national, regional and global mechanisms for assessing the quality of higher education, among which the main ones are accreditation and rating (OECD, 2009; University Quality ..., 2015; Lugovyi, Orzhel, Slyusarenko \& Talanova, 2018; Lugovyi, Slyusarenko \& Talanova, 2019a, 2019b, 2018a, 2018b; Lugovyi \& Talanova (eds.) et al., 2018; Slyusarenko, 2015; Talanova, 2010; Kremen, V., Luhovyi, V. et al. (eds.)., 2018).

In this regard, the author's publications reveal the essential opportunities, advantages and disadvantages of these mechanisms. It is proved that the rating is a more progressive and effective mechanism for monitoring the competitive quality of higher education than accreditation, especially in the context of development and for the key agents of this development, which are universities by their missions (Lugovyi, Orzhel, Slyusarenko \& Talanova, 2018; Lugovyi, Slyusarenko \& Talanova, 2019a, 2019b, 2018a, 2018b; Lugovyi \& Talanova (eds.) et al., 2018; Slyusarenko, 2015).

Ukraine, with more than 25 years of accreditation experience and in the absence of a national rating of higher education institutions (HEIs), has failed to bring its national higher education to a competitive level (Lugovyi, Slyusarenko \& Talanova, 2019b). The example of Ukraine confirms that accreditation as a certain threshold mechanism proved in principle incapable of curbing the chaotic expansion of the HEIs network, such as 73 universities, academies, institutes appeared in the country in 1994 (Lugovyi, Slyusarenko \& Talanova, 2019a). Thus, it is only natural that Ukraine by general and subject versions of Academic Ranking of World Universities (ARWU) remains a white spot on the European continent in a few countries, is out of process on building a worldclass higher education system (8th International Conference..., 2019; Academic Ranking..., 2019a, 2019b; Shanghai Ranking's..., 2019). At the same time, according to other, less objective ratings of The Times Higher Education World University Rankings ("Times") (THE..., 2019) and QS World University Rankings ("QS") (QS..., 2019), the positions of the group of Ukrainian universities have generally deteriorated. Therefore, analysis of the long stagnation of domestic higher education, finding out its cause and coping mechanisms are not taken off the agenda.

\section{LITERATURE REVIEW}

The article uses both author's research on the systematic review of the problem and other recent publications, including UNESCO, the Organization for Economic Co-operation and Development (OECD), World Bank, EU, ARWU, Times, and QS (UNDP, 2018; OECD, 2009, 2019a, 2019b; Review ..., 2019; University Quality .., 2015; Academic Ranking ..., 2019a, 2019b; ShanghaiRanking's ..., 2019; THE ..., 2019; QS ..., 2019). Also, data released in 2019 by the State 
Statistics Committee of Ukraine and the Information System "Konkurs" (Derzhstat Ukrainy, 2019; Informatsiina systema..., 2019) were also involved.

From the documents of the last Bologna Summit in Paris 2018, it follows that the EHEA has now shifted its focus from influential rating to less influential accreditation, which is obviously insufficient to realize the declared competitiveness and attractiveness of the EHEA in a globalized and competitive world (Kremen, Lugovyi, et al. (eds.): pp. 31, 438-477). Although the accreditation mechanism is capable of enhancing comparability, compatibility and coheritability of higher education in Europe, it is not a priori capable of fostering competitive development. Thus, as noted in V. Kremen's article citing H. Schmidt's research, at the end of 2017, "European companies controlled only $3 \%$ of the market for the latest innovations, while American companies - $64 \%$ and Asian ones - 31 \%" (Kremen, 2019). It is obvious that European universities are largely responsible for this situation. After all, they have a significantly higher share of R\&D funding than North American and especially East Asian HEIs (Luhovyi, Slyusarenko \& Talanova, 2019a; OECD, 2019b).

In predicting the role and development of higher education in the context of globalization, the OECD in Higher Education to 2030 (2009) summarized the specificities and trends that are confirmed ten years later. These include: "Co-operation and competition are intensifying simultaneously" (OECD, 2009: p. 13), and "Focus on quality assurance will strengthened in response to the growing importance of private and cross-border higher education, institutional rankings and the quest for accountability" (OECD, 2009: p. 15). All the while, the following statement is important for understanding the limits of accreditation: "At the same time, one can observe the emergence of cross-border accreditation and a general strengthening of co-operation across borders: several regional networks of quality assurance agencies have been established and there is an increasing interest in establishing common regional criteria and methodologies, particularly in Europe. The emergence of a common quality assurance framework on a global scale does not, however, seem likely in the near future" (OECD, 2009: p. 15).

In EU “The 'Europe 2020 Strategy' and other EU initiatives call for more excellence in Europe's higher education institutions in order to improve their performance, international attractiveness and competitiveness." In this regard the Study University Quality Indicators "examines separately two different quality approaches, quality assurance and rankings" in order to provide "Recommendations and policy options for the Parliament”. (University Quality ..., 2015: p. 1).

Unlike that accreditation, university rankings are recognized as a mechanism not only to ensure, but also to improve, the quality of higher education with broad national and global capabilities. This is accentuated by the site IREG Observatory on Academic Ranking and Excellence (IREG Observatory): "National and international academic rankings play ever increasing role as a barometer of quality of higher education institutions" (IREG ..., 2019). On Conference IREG in Bologna, Italy 8-10 May 2019 "Rankings: A Challenge to Higher Education?", in contrast to the thematic focus of previous conferences, a deeper understanding of the rankings and their fundamental role for universities has been made: "The growth of university rankings have not been neutral to the way higher education functions both on the national and the global scale. Some governments have been pouring billions of dollars into the "excellence initiatives" to elevate international position of their universities; universities themselves, rankings in mind, have been implementing policies hoping to increase their competitiveness and international visibility. Rankings have become more sophisticated and statistically robust. Many institutions seem to have figured out that there is something to learn from them even if they disapprove of the methodology or dislike the results" (Rankings: A Challenge ..., 2019).

Balance of world-class universities roles in enhancing global integration and strengthening nation priorities, and promotion their excellence initiatives while optimizing national higher education systems discussed during International conference "World-Class Universities: Globalization and National Models" 15-17 October 2019. This event was organized by the Center 
for World-Class Universities at Shanghai Jiao Tong University and supported by ShanghaiRanking Consultancy, that responsible for ARWU realization ( $8^{\text {th }}$ International ..., 2019). Such Chinese attention to university rankings has made it possible to increase the number of ARWU Chinese world-class universities four times in the past 15 years and to rank second after the United States in 2019 (Academic Ranking..., 2019a).

As for Ukraine, according to World Bank 2019 there is "strong reason to believe that the education system needs to change or risk falling behind" and "the systems that educate the next generation must constantly evolve and adapt to a fast-changing world" (Review ..., 2019: p. 4). The Ukrainian "higher education system is expansive, with a large number of specialized HEIs that are relatively small in size and scope. This has caused the system to become oversized and inefficient, especially in relation to the shrinking student population. Despite spending a relatively high share of public resources, funds are spread thinly across many institutions and staff". "Managerial capacity within HEIs for internal quality assurance and institutional selfimprovement is limited in many cases" (Review ..., 2019: p. 14). The Report emphasizes the need to "provide independent assessment of the progress of the HEI" (Review ..., 2019: p. 15). "Ukraine could introduce additional mechanisms to incentivize the consolidation or merger of higher education programs and/or institutions." (Review ..., 2019: p. 18). In addition, "assessment is also required to hold actors accountable for improving service delivery and achieving results" (Review ..., 2019: p. 22). "Currently, there is also very limited public information allowing young people to compare programs, fields of study, university rankings". "Moving forward, Ukraine needs to prioritize $[\ldots]$ improving data collection systems and performance monitoring in higher education." (Review ..., 2019: p. 23). "This could include the introduction of university rankings" (Review ..., 2019: p. 25).

The Program of Activities of the Cabinet of Ministers of Ukraine (2019), which complies with the recommendations of the World Bank, defines "Objective 1.4. Higher education graduates are competitive professionals in the labor market." The Program also states: "Public funding will be provided to those higher education providers who have better educational and scientific outcomes and create better life prospects for future graduates. In this case, all rectors will have key performance indicators in the contracts and will be evaluated on the results of their achievement." (Pro Prohramu diialnosti ..., 2019). That is, the program actualizes the problem of developing higher education and identifying the best HEIs in Ukraine.

Based on the review of the literature, there is a growing role and practical need for university rankings for social and economic development, both globally and nationally. It is also clear that Ukraine is suffering from an underdeveloped culture of rating, quality assurance and improvement in higher education. This determines the purpose of the article - to substantiate the need for urgent development and implementation of a national HEIs rating in Ukraine as a condition for the enhancement of higher education in the context of global globalization and European integration.

\section{METHODOLOGY}

The study applied, validated and developed the methodological proposition that the university mission determines the place and role of HEIs in society and the economy, forms the criterion basis for their status classification, and determines the appropriate mechanisms for assessing the competitiveness of institutional achievements. For the purposes of the study, we have used big data bases of UNESCO, OECD, international rankings, State Statistics Service of Ukraine, Competition Information System (UNDP, 2018; OECD, 2009, 2019a, 2019b; Review ..., 2019; Academic Ranking ..., 2019a, 2019b; ShanghaiRanking's ..., 2019; THE ..., 2019; QS ..., 2019; Derzhstat Ukrainy, 2019; Informatsiina systema..., 2019). This research is part of a comprehensive meta-study on university capacity development that has been consistently carried out by the authors over the last 
decade (Lugovyi, Orzhel, Slyusarenko \& Talanova, 2018; Lugovyi, Slyusarenko \& Talanova, 2019a, 2019b, 2018a, 2018b; Lugovyi \& Talanova (eds.), 2018; Slyusarenko, 2015; Talanova, 2010).

\section{MAIN RESULTS}

The prolonged stagnation of national higher education, which has been diagnosed in author publications in previous years, has been reaffirmed in the World Bank review and in leading international rankings in 2019 (Review..., 2019; Academic Ranking..., 2019a, 2019b; ShanghaiRanking's..., 2019; THE... , 2019; QS..., 2019). Moreover, in the context of the progress of university education in many developing countries, Ukraine is increasingly moving to the brink of global progress in the competitiveness of national higher education.

In this regard, the World Bank offers a look "at system performance along three dimensions: effectiveness, including quality and relevance; equity and inclusion; and efficiency of resource use." (Review...,2019:p.5) and note that "there is little systematic information on the quality of learning outcomes in higher education" (Review..., 2019: p. 6), "and to the public sense that the education system is no longer meeting the needs of students, families and employers." (Review..., 2019: p. 8). It is also stated that to this day, "there is no clear or coherent vision for the development of the higher education sector or individual universities. This is a fundamental problem: higher education in Ukraine cannot serve the needs of the people and the economy without clear goals and a strategy for how to achieve them." Because "individual HEIs use their autonomy to achieve individual goals rather than working to achieve a broader goal for the system and nation." (Review..., 2019: p. 13). Therefore, according to the World Bank recommendations in particular Priorities for Action under Ukraine's Education Reform The short-term agenda should include "Develop criteria for university rankings" (Review..., 2019: p. 26) in order to "steer the system towards longer term competitiveness, innovation, productivity growth, and sustainability." (Review..., 2019: p. 12).

Just implementation of the World Bank recommendations requires a national rating of HEIs of general (institutional), sectoral, and in the Ukrainian context, and regional versions. After all, the purely objective ARWU does not notice domestic institutions at all. Only one-third subjective "Times" captures Lviv Polytechnic National University in the 800-1000 group, the other five institutions are outside the top 1000, worse than in 2016 and 2017, and the National Technical University of Ukraine "Igor Sikorsky Kyiv Polytechnic Institute" fell out of the rankings altogether. Half subjective "QS" - ranks six Ukrainian institutions within the 491-800 group, four of which have underperformed since 2015 (Academic Ranking..., 2019a, 2019b; ShanghaiRanking's..., 2019; THE..., 2019; QS ..., 2019) (see Table 1).

According to the criterion of J. Salmi, who in 2009 classified as a world-class university in the first 500 ARWU positions (as well as in the Top 200 "Times") (Salmi, 2009), there are no such universities in Ukraine. There are no subworld-class institutions (so-called world-class candidates) in the country and are now ranked 501-1000 in this ranking (Academic Ranking..., 2019a, 2019b; ShanghaiRanking's..., 2019; Lugovyi, Slyusarenko \& Talanova, 2018).

At the same time, based on Table 1, it can be considered that the best national institutions in Ukraine are now four classical universities (V.N. Karazin Kharkiv National University, Taras Shevchenko National University of Kyiv, Ivan Franko National University of Lviv, Sumy State University) and three technical universities (Lviv Polytechnic National University, National Technical University "Kharkiv Polytechnic Institute" and National Technical University of Ukraine "Igor Sikorsky Kyiv Polytechnic Institute"). Vasyl Stus Donetsk National University has lost its leading position. The composition of these universities suggests a typical model of organization of leading universities in Ukraine at national and subnational levels - a twin development of classical and technical universities in the process of enlargement of institutions. Five domestic Nobel laureates in Kharkiv, Odessa, and Simferopol studied and worked in these types of institutions (until 1937) (Slyusarenko, 2015: p. 283). 


\section{Ranks of national HEIs according to "Times" and "QS" ratings released in 2012-2019}

\begin{tabular}{|c|c|c|c|c|c|c|c|c|c|c|}
\hline № & HEIs & \multicolumn{9}{|c|}{ Ranks by year (total number of places in rating) } \\
\hline 1 & 2 & 3 & 4 & 5 & 6 & 7 & 8 & 8 & 10 & 11 \\
\hline \multicolumn{11}{|c|}{ I. “Times" Rating } \\
\hline & & $\begin{array}{l}2012 \\
(402)\end{array}$ & $\begin{array}{l}2013 \\
(400)\end{array}$ & $\begin{array}{l}2014 \\
(400)\end{array}$ & $\begin{array}{l}2015 \\
(401)\end{array}$ & $\begin{array}{l}2016 \\
(800)\end{array}$ & $\begin{array}{l}2017 \\
(981)\end{array}$ & $\begin{array}{c}\mathbf{2 0 1 8} \\
(1103)\end{array}$ & $\begin{array}{l}2019 \\
(1258)\end{array}$ & $\begin{array}{c}\mathbf{2 0 2 0} \\
(1396)\end{array}$ \\
\hline \multicolumn{11}{|c|}{ Comprehensive Universities } \\
\hline 1 & $\begin{array}{l}\text { Taras Shevchenko National } \\
\text { University of Kyiv } \\
\end{array}$ & & & & & $\begin{array}{c}601- \\
800\end{array}$ & $>800$ & $\begin{array}{l}801- \\
1000 \\
\end{array}$ & $1001+$ & $1001+$ \\
\hline 2 & $\begin{array}{l}\text { Ivan Franko National University } \\
\text { of Lviv }\end{array}$ & & & & & & & $1001+$ & $1001+$ & $1001+$ \\
\hline 3 & Sumy State University & & & & & & & & & $1001+$ \\
\hline 4 & $\begin{array}{l}\text { V.N. Karazin Kharkiv National } \\
\text { University }\end{array}$ & & & & & $\begin{array}{l}601- \\
800\end{array}$ & $>800$ & $1001+$ & $1001+$ & $1001+$ \\
\hline \multicolumn{11}{|c|}{ Technical Universities } \\
\hline 1 & $\begin{array}{l}\text { National Technical University } \\
\text { of Ukraine "Igor Sikorsky Kyiv } \\
\text { Polytechnic Institute" }\end{array}$ & & & & & & $>800$ & $1001+$ & - & - \\
\hline 2 & $\begin{array}{l}\text { Lviv Polytechnic National } \\
\text { University }\end{array}$ & & & & & & $>800$ & $1001+$ & $1001+$ & $\begin{array}{l}801- \\
1000 \\
\end{array}$ \\
\hline 3 & $\begin{array}{l}\text { National Technical University } \\
\text { "Kharkiv Polytechnic Institute" }\end{array}$ & & & & & & & & & $1001+$ \\
\hline \multicolumn{11}{|c|}{ II. “QS” Rating } \\
\hline & & 2012 & 2013 & 2014 & 2015 & $\begin{array}{l}2016 \\
(891)\end{array}$ & $\begin{array}{l}2017 \\
(916)\end{array}$ & $\begin{array}{l}2018 \\
(959)\end{array}$ & $\begin{array}{c}2019 \\
(1000)\end{array}$ & $\begin{array}{l}\mathbf{2 0 2 0} \\
(1002)\end{array}$ \\
\hline \multicolumn{11}{|c|}{ Comprehensive Universities } \\
\hline 1 & $\begin{array}{l}\text { V.N. Karazin Kharkiv National } \\
\text { University }\end{array}$ & & & & \begin{tabular}{c|}
$481-$ \\
490 \\
\end{tabular} & $\begin{array}{c}491- \\
500\end{array}$ & 382 & $\begin{array}{c}401- \\
410\end{array}$ & 481 & 491 \\
\hline 2 & $\begin{array}{l}\text { Taras Shevchenko National } \\
\text { University of Kyiv }\end{array}$ & $\begin{array}{c}501- \\
550\end{array}$ & & $\begin{array}{c}441- \\
450\end{array}$ & $\begin{array}{c}421- \\
430\end{array}$ & $\begin{array}{c}421- \\
430\end{array}$ & $\begin{array}{c}431- \\
440\end{array}$ & $\begin{array}{l}411- \\
420\end{array}$ & $\begin{array}{c}531- \\
540\end{array}$ & $\begin{array}{c}541- \\
550\end{array}$ \\
\hline 3 & Sumy State University & & & & $\begin{array}{c}651- \\
700\end{array}$ & $701+$ & $701+$ & $\begin{array}{l}801- \\
1000\end{array}$ & $\begin{array}{c}751- \\
800\end{array}$ & $\begin{array}{c}701- \\
750\end{array}$ \\
\hline 4 & $\begin{array}{l}\text { Vasyl' Stus Donetsk National } \\
\text { University }\end{array}$ & & & & & & $701+$ & $\begin{array}{l}801- \\
1000\end{array}$ & - & - \\
\hline \multicolumn{11}{|c|}{ Technical Universities } \\
\hline 1 & $\begin{array}{l}\text { National Technical University } \\
\text { "Kharkiv Polytechnic Institute" }\end{array}$ & & & $701+$ & $701+$ & $701+$ & $701+$ & $\begin{array}{l}701- \\
750\end{array}$ & $\begin{array}{c}701- \\
750\end{array}$ & $\begin{array}{c}651- \\
700\end{array}$ \\
\hline 2 & $\begin{array}{l}\text { National Technical University } \\
\text { of Ukraine "Igor Sikorsky Kyiv } \\
\text { Polytechnic Institute" }\end{array}$ & $601+$ & & $\begin{array}{c}601- \\
650\end{array}$ & $\begin{array}{c}551- \\
600\end{array}$ & $\begin{array}{c}601- \\
650\end{array}$ & $\begin{array}{c}551- \\
600\end{array}$ & $\begin{array}{c}501- \\
550\end{array}$ & $\begin{array}{c}601- \\
650\end{array}$ & $\begin{array}{c}701- \\
750\end{array}$ \\
\hline 3 & $\begin{array}{l}\text { Lviv Polytechnic National } \\
\text { University }\end{array}$ & & & & & & & & $\begin{array}{c}751- \\
800\end{array}$ & $\begin{array}{c}751- \\
800\end{array}$ \\
\hline
\end{tabular}

Source: Compiled by the authors based on: THE ..., 2019; QS ..., 2019. 
However, all of these institutions do not meet the ARWU criteria and, in addition, are virtually impossible to rank among themselves without a recognized valid national rating. In addition, such a rating is indispensable in terms of identifying institutions that, although accredited, yet constitute a group of outsiders who are unable to work for progress, pose risks in higher education. As for the other of 282 Ukrainian HEIs and numerous non-core structural units (Derzhstat Ukrainy, 2019; Informatsiina systema...,2019), there is little to say objectively about their achievements and potential. Many domestic institutions, although accredited, can only be tentatively called higher education institutions (Lugovyi, Slyusarenko \& Talanova, 2019b; Lugovyi \& Talanova (eds.), 2018).

Ranking the top international university rankings in order of priority: 1) ARWU, 2) "Times" and 3) "QS", as justified in the paper (Slyusarenko, 2015) and defined by governmental order (Pro zatverdzhennia pereliku..., 2018), important above all elaborate on the indirect reflection of Ukrainian positions in the mirror of the most objective ARWU general and subject versions.

The breakdown of university achievement by ARWU is illustrated in Fig. 1.

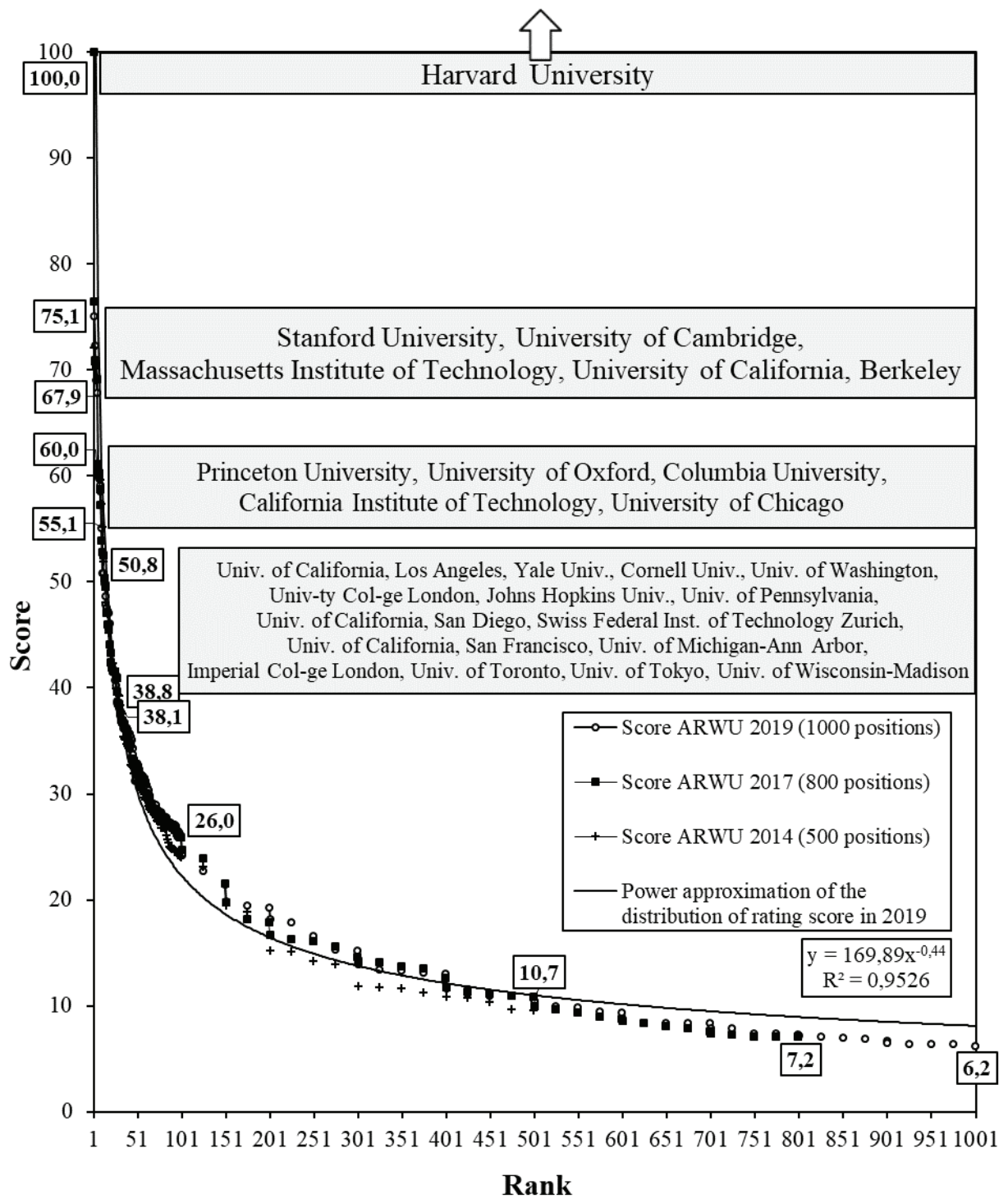

Fig. 1. Breakdown of university grades by ARWU rankings in general. Ukraine is not in the ranking

Source: Compiled by the authors based on: Academic Ranking ..., 2019a, 2019b. 
Figs. 1 shows the high resolution of ARWU for top institutions and the appropriate group stratification of extra class institutions (1-30 positions). This ability to clearly identify the top leaders in world development makes the ranking, especially with the introduction of ARWU by academic subjects, a base when considering key agents of global progress - world-class universities. According to ARWU, there are neither world-class nor subworld-class universities in Ukraine.

From Table 2 it is clear that Ukraine is inferior to many countries in terms of competitiveness of higher education.

Table 2

Countries represented in the 2019 ARWU general version

\begin{tabular}{|c|l|c|c|c|}
\hline \multirow{2}{*}{$\mathbf{N}$} & \multirow{2}{*}{ Groups of countries } & \multicolumn{3}{|c|}{$\begin{array}{c}\text { Ranking places, } \\
\text { Number (list) of countries }\end{array}$} \\
\cline { 3 - 5 } & & $1-500$ & $501-1000$ & $1-1000$ \\
\hline 1 & 2 & 3 & 4 & 5 \\
\hline 1 & All countries & 44 & 17 & $61^{2}$ \\
\hline 2 & Europe & 24 & 8 & 32 \\
\hline \multirow{2}{*}{3} & Neighbouring countries & $\begin{array}{c}\text { (Poland, Russia, } \\
\text { Turkey) }\end{array}$ & $\begin{array}{c}\text { (Bulgaria, Romania, Slovakia, } \\
\text { Hungary) }\end{array}$ & 7 \\
\hline \multirow{2}{*}{4} & $\begin{array}{l}\text { Small countries (Population } \\
\text { less than 4.0 million) }\end{array}$ & $\begin{array}{c}5 \\
\text { (Estonia, Iceland) }\end{array}$ & $\begin{array}{c}\text { (Cyprus, Lithuania, } \\
\text { Luxembourg, Slovenia, Uruguay) }\end{array}$ & 7 \\
\hline
\end{tabular}

Source: Compiled by the authors based on: Academic Ranking ..., 2019a, $2019 b$.

Note: ${ }^{1} 47$ with selection of China-Hong Kong, China-Macau i China-Taiwan.

${ }^{2} 64$ with selection of China-Hong Kong, China-Macau i China-Taiwan.

Table 3 shows the total systemic backlog of Ukrainian university education in all 54 ARWU subject areas.

Table 3

Achievements of HEIs in Ukraine, neighbouring countries ${ }^{1}$ and small ${ }^{2}$ European countries and Croatia ${ }^{3}$ by academic subjects of ARWU 2017, 2018 and 2019

\begin{tabular}{|c|c|c|c|c|c|c|c|c|c|c|c|c|c|c|c|c|c|c|c|c|c|}
\hline \multirow[b]{3}{*}{$\mathbf{N}$} & \multirow{3}{*}{$\begin{array}{c}\text { Years } \\
\text { (number subjects } \\
\text { in subjects' group, } \\
\text { total number of } \\
\text { places by subjects' } \\
\text { groups) }\end{array}$} & \multirow[b]{3}{*}{ 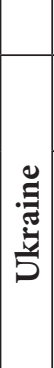 } & \multicolumn{19}{|c|}{ Number of HEI's ranked by subjects' groups in 2017, 2018 and 2019} \\
\hline & & & \multicolumn{10}{|c|}{ Neighbouring countries $^{1}$} & \multicolumn{9}{|c|}{$\begin{array}{c}\text { Small }^{2} \text { European countries } \\
\text { and Croatia }\end{array}$} \\
\hline & & & 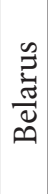 & 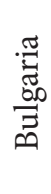 & 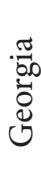 & $\begin{array}{l}\overrightarrow{\tilde{J}} \\
\text { ज्ञ } \\
0\end{array}$ & $\begin{array}{l}. \frac{\pi}{2} \\
0 \\
\overrightarrow{2} \\
2\end{array}$ & 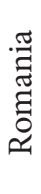 & 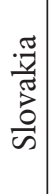 & $\begin{array}{l}\widehat{\vec{y}} \\
\frac{\vec{y}}{3} \\
\vec{y}\end{array}$ & 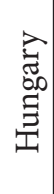 & 풍 & 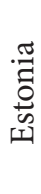 & 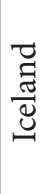 & 芯 & 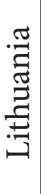 & 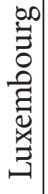 & 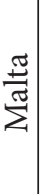 & $\begin{array}{l}. \frac{a}{Z} \\
\overrightarrow{0} \\
\frac{0}{\omega}\end{array}$ & 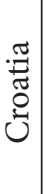 & 吾 \\
\hline 1 & 2 & 3 & 4 & 5 & 6 & 7 & 8 & 9 & 10 & 11 & 12 & 13 & 14 & 15 & 16 & 17 & 18 & 19 & 20 & 21 & 22 \\
\hline \multicolumn{22}{|c|}{ I. Natural Sciences } \\
\hline 1 & $2017(6,2300)$ & 1 & 1 & 1 & 2 & 15 & 16 & 8 & 3 & 26 & 5 & 78 & 3 & 2 & 1 & 2 & & & 6 & 3 & 17 \\
\hline 2 & $2018(8,3200)$ & & 1 & 1 & 2 & 19 & 23 & 9 & 2 & 30 & 10 & 97 & 7 & 2 & 1 & 3 & & & 8 & 4 & 25 \\
\hline
\end{tabular}




\begin{tabular}{|c|c|c|c|c|c|c|c|c|c|c|c|c|c|c|c|c|c|c|c|c|c|}
\hline 3 & $2019(8,3397)$ & & 1 & 1 & 1 & 29 & 24 & 9 & 4 & 26 & 10 & 105 & 8 & 5 & 1 & 3 & & & 9 & 4 & 30 \\
\hline 4 & $\begin{array}{l}2019 / 2017 \\
(1.3 ; 1.5)\end{array}$ & & & & & & & & & & & 1.3 & & & & & & & & & 1.8 \\
\hline \multicolumn{22}{|c|}{ II. Engineering } \\
\hline 1 & $2017(22,5700)$ & & & & & 18 & 15 & 3 & 1 & 24 & 5 & 66 & 2 & 1 & 4 & 1 & 3 & & 10 & 2 & 23 \\
\hline 2 & $2018(22,6694)$ & & & & & 49 & 29 & 14 & 1 & 53 & 6 & 152 & 4 & 1 & 2 & 2 & 2 & & 13 & 8 & 32 \\
\hline 3 & $2019(22,6900)$ & & & & & 36 & 31 & 5 & 1 & 39 & 4 & 116 & 1 & 1 & 1 & 1 & 4 & & 13 & 6 & 27 \\
\hline 4 & $\begin{array}{l}2019 / 2017 \\
(1.0 ; 1.2)\end{array}$ & & & & & & & & & & & 1.8 & & & & & & & & & 1.2 \\
\hline \multicolumn{22}{|c|}{ III. Life Sciences } \\
\hline 1 & $2017(4,1700)$ & & & & & 10 & 1 & & & 2 & 3 & 16 & 5 & 1 & & 1 & & & 4 & 4 & 15 \\
\hline 2 & $2018(4,1800)$ & & & & & 13 & 2 & & 1 & 6 & 3 & 25 & 5 & 2 & & 2 & 2 & & 4 & 4 & 19 \\
\hline 3 & $2019(4,1800)$ & & & & & 13 & 1 & 1 & 2 & 5 & 3 & 25 & 6 & 2 & & 1 & 2 & & 3 & 4 & 18 \\
\hline 4 & $\begin{array}{l}2019 / 2017 \\
(1.0 ; 1.1)\end{array}$ & & & & & & & & & & & 1.6 & & & & & & & & & 1.2 \\
\hline \multicolumn{22}{|c|}{ IV. Medical Sciences } \\
\hline 1 & $2017(6,2000)$ & & & & & 9 & 1 & 1 & & 6 & 4 & 21 & 3 & 2 & & & & & 4 & 3 & 12 \\
\hline 2 & $2018(6,2400)$ & & & 1 & & 12 & 1 & 1 & & 23 & 5 & 43 & 2 & 3 & 1 & 1 & & & 4 & 4 & 15 \\
\hline 3 & $2019(6,2500)$ & & & & & 11 & 1 & 4 & & 19 & 8 & 43 & 3 & 3 & 1 & 1 & & 1 & 5 & 3 & 17 \\
\hline 4 & $\begin{array}{l}2019 / 2017 \\
(1.0 ; 1.3) \\
\end{array}$ & & & & & & & & & & & 2.0 & & & & & & & & & 1.4 \\
\hline \multicolumn{22}{|c|}{ V. Social Sciences } \\
\hline 1 & $2017(14,2700)$ & & & & & & 3 & 1 & & 9 & 2 & 15 & & & 1 & 1 & 2 & & 3 & & 7 \\
\hline 2 & $2018(14,4400)$ & & & & & 6 & 7 & 4 & & 24 & 6 & 47 & 5 & 1 & 3 & 2 & 4 & & 10 & 2 & 27 \\
\hline 3 & $2019(14,4594)$ & & & & & 6 & 7 & 4 & & 23 & 6 & 46 & 5 & 3 & 4 & 2 & 5 & 1 & 12 & 3 & 35 \\
\hline 4 & $\begin{array}{l}\text { 2019/2017 (1.0; } \\
1.7)\end{array}$ & & & & & & & & & & & 3.1 & & & & & & & & & 5.0 \\
\hline \multicolumn{22}{|c|}{ All Ranking Subjects } \\
\hline 1 & $2017(52,14400)$ & 1 & 1 & 1 & 2 & 52 & 36 & 13 & 4 & 67 & 19 & 196 & 13 & 6 & 6 & 5 & 5 & & 27 & 12 & 74 \\
\hline 2 & $2018(54,18494)$ & & 1 & 2 & 2 & 99 & 62 & 28 & 4 & 136 & 30 & 364 & 23 & 9 & 7 & 10 & 8 & & 39 & 22 & 118 \\
\hline 3 & $2019(54,19191)$ & & 1 & 1 & 1 & 95 & 64 & 23 & 7 & 112 & 31 & 335 & 23 & 14 & 7 & 8 & 11 & 2 & 42 & 20 & 127 \\
\hline 4 & $\begin{array}{l}2019 / 2017 \\
(1.04 ; 1.3)\end{array}$ & & & & & & & & & & & 1.7 & & & & & & & & & 1.7 \\
\hline
\end{tabular}

Source: Compiled by the authors based on: ShanghaiRanking's ..., 2019.

Note: ${ }^{1}$ Except Moldova.

${ }^{2}$ Population less than 3.0 million.

${ }^{3}$ Population 4.2 million.

Table 4 shows the dynamics of extending HEIs coverage by the academic subject version of ARWU. 
Comparison of subject rankings of HEIs by ARWU 2017, 2018 and 2019

\begin{tabular}{|c|c|c|c|c|c|}
\hline \multirow[b]{2}{*}{$\mathbf{N}$} & \multirow[b]{2}{*}{ Rating parameter } & \multicolumn{4}{|c|}{ Years } \\
\hline & & 2017 & 2018 & 2019 & $\begin{array}{l}\text { 2019/2017, } \\
\text { times }\end{array}$ \\
\hline 1 & 2 & 3 & 4 & 5 & 6 \\
\hline 1 & Methodology including 5 indicators & \multicolumn{4}{|c|}{ No changes } \\
\hline 2 & Number of awards (subjects) identified & $27(19)$ & $27(22)$ & $26(23)$ & $0,96(1,21)$ \\
\hline 3 & Number of top magazines (subjects) & $94(33)$ & $123(41)$ & $134(45)$ & $1,43(1,36)$ \\
\hline 4 & Number of top conferences (subjects) & - & $14\left(1^{1}\right)$ & $17\left(1^{1}\right)$ & \\
\hline 5 & Number of subjects & 52 & 54 & 54 & 1,04 \\
\hline 6 & Number of examined institutions & $\begin{array}{c}>4 \\
\text { thousand }\end{array}$ & $\begin{array}{c}>4 \\
\text { thousand }\end{array}$ & $\begin{array}{c}>4 \\
\text { thousand }\end{array}$ & 1,00 \\
\hline 7 & Total number of places by subjects & $\begin{array}{c}14,4 \\
\text { thousand }\end{array}$ & $\begin{array}{c}>18,4 \\
\text { thousand }\end{array}$ & $\begin{array}{c}19,2 \\
\text { thousand }\end{array}$ & 1,33 \\
\hline 8 & Number of countries in the ranking & 80 & 83 & 86 & 1,08 \\
\hline 9 & Number of institutions in the rating & $\begin{array}{c}>1,4 \\
\text { thousand }\end{array}$ & $\begin{array}{c}>1,6 \\
\text { thousand }\end{array}$ & $\begin{array}{c}>1,7 \\
\text { thousand }\end{array}$ & 1,21 \\
\hline 10 & Number of USA places ( $1^{\text {st }}$ place) & 3857 & 4661 & 4808 & 1,25 \\
\hline 11 & Number of Chinese places ( $2^{\text {nd }}$ place $)$ & 1652 & 2171 & 2451 & 1,48 \\
\hline 12 & $\begin{array}{l}\text { Number of places for UK institutions } \\
\left(3^{\text {rd }} \text { place }\right)\end{array}$ & 1168 & 1487 & 1554 & 1,33 \\
\hline 13 & Harvard University ( $1^{\text {st }}$ place in subjects) & 15 & 17 & 14 & 0,93 \\
\hline 14 & $\begin{array}{l}\text { Massachusetts Institute of Technology } \\
\left(2^{\text {nd }} \text { place in subjects }\right)\end{array}$ & 5 & 5 & 5 & 1,00 \\
\hline
\end{tabular}

Source: Compiled by the authors based on: ShanghaiRanking's ..., 2019.

Note: ${ }^{1} 17$ top academic conferences in computer science and engineering.

From Table 5 it is easy to see that Ukraine is in the group of countries with a competitive disadvantage in higher education.

Table 5

Distribution $^{1}$ countries (50) located in Europe by presence in ARWU 2019

\begin{tabular}{|c|l|l|l|}
\hline $\mathbf{N}$ & Parameter & \multicolumn{1}{|c|}{$\begin{array}{c}\text { Group of countries } \\
\text { presented in the ranking }\end{array}$} & $\begin{array}{l}\text { Group of countries absent } \\
\text { in the ranking }\end{array}$ \\
\hline 1 & 2 & \multicolumn{1}{|c|}{3} & \multicolumn{1}{c|}{4} \\
\hline 1 & $\begin{array}{l}\text { Names (list) } \\
\text { of countries } \\
\text { in the group }\end{array}$ & $\begin{array}{l}\text { Russia, Germany, Turkey, France, United } \\
\text { Kingdom, Italy, Spain, Poland, Romania, } \\
\text { Netherlands, Belgium, Greece, Czech } \\
\text { Republic, Portugal, Sweden, Hungary, } \\
\text { Belarus, Austria, Switzerland, Bulgaria, } \\
\text { Serbia, Denmark, Finland, Slovakia, Norway, } \\
\text { Ireland, Croatia, Georgia, Lithuania, Slovenia, } \\
\text { Estonia, Cyprus, Luxembourg, Malta, Iceland }\end{array}$ & $\begin{array}{l}\text { Ukraine, Kazakhstan, } \\
\text { Azerbaijan, Bosnia and } \\
\text { Herzegovina, Armenia, } \\
\text { Moldova, Albania, Northern } \\
\text { Macedonia, Latvia, } \\
\text { Montenegro, Andorra, } \\
\text { Liechtenstein, Monaco, San } \\
\text { Marino, Vatican }\end{array}$ \\
\hline
\end{tabular}




\section{Number}

(percentage,

$\%)$

of countries

in the group

Source: Compiled by the authors based on: Academic Ranking ..., 2019a, 2019b; ShanghaiRanking's ..., 2019.

Note: ${ }^{1}$ Countries in groups are listed in order of decreasing population (from the largest Russia, 144.0 million, to the smallest - the Vatican, 1 thousand population).

Table 6 shows that the resource potential of Ukraine is outweighed by the potential of a number of countries with university representatives in ARWU.

Table 6

\section{Comparison of Ukraine with neighbouring and small ${ }^{1}$ countries with HEIs in ARWU 2019 and less than Ukrainian GDP}

\begin{tabular}{|c|c|c|c|c|c|}
\hline \multirow[t]{2}{*}{$\mathbf{N}$} & \multirow[t]{2}{*}{ Countries } & \multirow{2}{*}{$\begin{array}{c}\text { GDP, } \\
\$ U S A, P P P^{2}\end{array}$} & \multirow{2}{*}{$\begin{array}{c}\text { GDP ratio of Ukraine } \\
\text { and other countries, } \\
\text { times }^{2}\end{array}$} & \multicolumn{2}{|c|}{$\begin{array}{l}\text { Number of HEI's } \\
\text { in the ranking }\end{array}$} \\
\hline & & & & $1-500$ places & 1-1000 places \\
\hline 1 & 2 & 3 & 4 & 5 & 6 \\
\hline 1 & Ukraine & 335.4 & & - & - \\
\hline \multicolumn{6}{|c|}{ Nneighbouring countries } \\
\hline 2 & Hungary & 261.9 & 1.3 & - & 5 \\
\hline 3 & Slovakia & 164.0 & 2.0 & - & 1 \\
\hline \multicolumn{6}{|c|}{ Small ${ }^{1}$ countries } \\
\hline 4 & Cyprus & 27.8 & 12.1 & - & 1 \\
\hline 5 & Estonia & 38.8 & 8.6 & 1 & 1 \\
\hline 6 & Iceland & 15.9 & 21.1 & 1 & 1 \\
\hline 7 & Lithuania & 83.5 & 4.0 & - & 1 \\
\hline 8 & Luxembourg & 56.5 & 5.9 & - & 1 \\
\hline 9 & Slovenia & 64.9 & 5.2 & & 2 \\
\hline 10 & Uruguay & 71.0 & 4.7 & - & 1 \\
\hline
\end{tabular}

Source: Compiled by the authors based on: Academic Ranking ..., 2019a, 2019b; UNDP, 2018.

Note: ${ }^{1}$ Which has less than 4 million people.

${ }^{2} \mathrm{PPP}$ - purchasing power parity.

In addition, the higher education strategy of the progressive countries includes providing universities with representatives in the list of the first 100 institutions in ARWU. In 2019, as in the previous year, 18 countries have such institutions, 11 (61\%) of them with a smaller population than in Ukraine. In the top 30 in recent years, six countries are represented: USA, UK, Switzerland, Canada, Japan and Denmark (Academic Ranking..., 2019a, 2019b).

The absence of world- / subworld-class universities in Ukraine is primarily due to the strong fragmentation and dispersion of the HEIs network, excessive duplication of training in them, as can be seen from Table 7 in the example of Kyiv and Kirovohrad region. 
Data on the admission in 2019 of applicants for specific specialties and fields of knowledge to the bachelor's level of full-time training in Kyiv and Kirovohrad region

\begin{tabular}{|c|c|c|c|c|c|c|c|c|c|c|c|c|c|c|}
\hline \multirow[b]{2}{*}{$\mathbf{N}$} & \multirow[b]{2}{*}{$\begin{array}{c}\text { Type, } \\
\text { quantity }^{1} \text {, } \\
\text { share of } \\
\text { institutions }\end{array}$} & \multicolumn{12}{|c|}{ Specialties / Fields of knowledge } & \multirow[b]{2}{*}{ 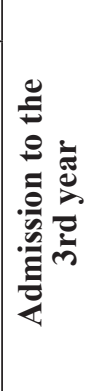 } \\
\hline & & 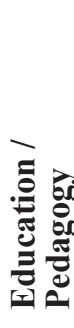 & $\frac{0}{\frac{0}{0}}$ & 节 & 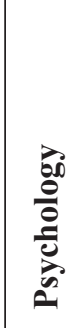 & 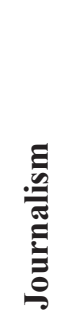 & 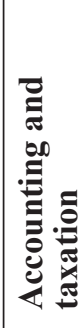 & 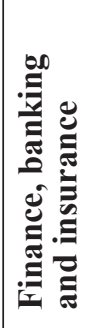 & 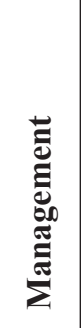 & E & 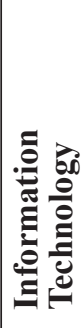 & 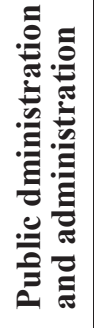 & 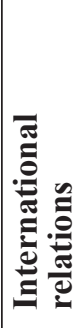 & \\
\hline 1 & 2 & 3 & 4 & 5 & 6 & 7 & 8 & 9 & 10 & 11 & 12 & 13 & 14 & 15 \\
\hline \multicolumn{15}{|c|}{ Kyiv } \\
\hline \multicolumn{15}{|c|}{ All institutions (63 universities, academies, institutes and 12 colleges) } \\
\hline 1 & Number & 14 & 18 & 28 & 20 & 14 & 23 & 31 & 37 & 37 & 30 & 13 & 23 & 43 \\
\hline 2 & Part, \% & 18.7 & 24.0 & 37.3 & 26.7 & 18.7 & 30.7 & 41.3 & 49.3 & 49.3 & 40.0 & 17.3 & 30.7 & 57.3 \\
\hline \multicolumn{15}{|c|}{ Kirovohrad region } \\
\hline \multicolumn{15}{|c|}{ All institutions (8 universities, academies, institutes) } \\
\hline 1 & Number & 1 & 1 & 3 & 2 & 1 & 4 & 3 & 4 & 6 & 2 & 2 & 1 & 6 \\
\hline 2 & Part, \% & 12.5 & 12.5 & 37.5 & 25.0 & 12.5 & 50.0 & 37.5 & 50.0 & 75.0 & 25.0 & 25.0 & 12.5 & 75.0 \\
\hline
\end{tabular}

Source: Compiled by the authors based on: Informatsiina systema..., 2019.

Note: ${ }^{1}$ Full-time admission institutions in 2019.

Table 7 shows, first, excessive duplication, and second, high dispersion of HEIs. For example, in the field of law, 37 institutions are being trained in Kyiv, and 6 in the Kirovohrad region. Approximately 8.5 thousand students in the Kirovohrad region study in 8 HEIs, that is, on average 1 thousand students per institution, while in Ukraine as a whole -4.7 thousand. In this respect, if the degree of duplication of training in Kiev generally stabilized, then in the Kirovohrad region - increased: the number of students in the oblast decreased by 0.3 thousand a year, while the number of institutions providing law education programs increased (Derzhstat Ukrainy, 2019; Informatsiina systema..., 2019).

The lack of awareness of the HEIs of their own university mission is one of the key reasons for the university gap (see Table 8).

Table 8

Comparison of key words of HE / HEIs missions in the definition of various associations (groups) of HEIs

\begin{tabular}{|c|l|c|c|c|c|}
\hline \multirow{2}{*}{$\mathbf{N}$} & \multirow{2}{*}{ Key words } & \multicolumn{4}{|c|}{ Associations (groups) of HEIs } \\
\cline { 3 - 6 } & & $\mathrm{AAU}^{1}$ & EUA $^{2}$ & EURASHE & Top-30 HEIs, ARWU \\
\hline 1 & 2 & 3 & 4 & 5 & 6 \\
\hline 1 & First word & Education & Education & Education & Education \\
\hline 2 & Second word & Research & Research & Research & Research \\
\hline \multirow{2}{*}{3} & \multirow{2}{*}{ Third words } & & Innovation & & Knowledge, Create \\
\cline { 3 - 6 } & & Service & & Service & \\
\hline
\end{tabular}

Source: Lugovyi, Orzhel, Slyusarenko \& Talanova, 2018; Slyusarenko, 2015.

Note: ${ }^{1}$ Association of American Universities.

${ }^{2}$ European University Association.

${ }^{3}$ European Association of Institutions in Higher Education. 
As seen from Table 8, the first keyword in HE / HEI missions is "Education", the second is "Research". While, the third keywords are different, such as: "Service”, "Innovation", "Knowledge", and "Create". It is the third terms that define the so-called third mission of the universities and serve as the criteria for the delineation of classical academic universities and universities of applied sciences. It is clear from the author's research that in the universities "Education" is integrated with "R\&D", forming "Higher Education", which (not R\&D) is the main activity of HEIs (Lugovyi, Orzhel, Slyusarenko \& Talanova, 2018; Lugovyi, Slyusarenko \& Talanova 2019a).

As for the Ukrainian practice of rating HEIs, it is not productive. The main flaws of various domestic rating attempts of the last decade ("National rating system for the assessment of HEIs activity", "Compass", “Consolidated”, "Top-200 Ukraine”, "Contract EIT ${ }^{1}$ Score”, "Scopus" and some others) - aspect, subjectivity, poor validity. This does not make it possible to reliably identify the positions of institutions in accordance with the university mission and its key constituents in the context of innovative type of progress. After all, the "National Rating System for the assessment of HEIs activity" and the "Compass" Rating are not implemented after 2013, other ratings are contradictory, and they are not credible, and therefore not influential. In these circumstances, each institution is oriented and orientates the others on profitable rating achievements. For example, Catholic University pays attention to $1^{\text {st }}$ place in the "Contract EIT Score" rating, although it is ranked $161^{\text {st }}$ place in the "Top-200 Ukraine", $167^{\text {th }}$ place in the "Scopus" rating in 2019, and $101^{\text {st }}$ place in "Consolidated Rating" (Kompas..., 2019; Konsolidovanyi reitynh ..., 2019; Pro zatverdzhennia Polozhennia..., 2011; Reitynh universytetiv..., 2019; Reitynh universytetiv «TOP-200 Ukraina», 2019). Therefore, depending on the rating disposition, the institution or leader (?), or outsider (?), or average (?) University. This situation is not professionally constructive or acceptable.

Additional disorientation of stakeholders in determining university achievement is made public by the rating evaluation of 110 (out of 118) "national institutions", drawn up on the basis of criteria approved by the Cabinet of Ministers of Ukraine (Nikulina, Kshevetskyi \& Tereshchuk, 2019).

Tables 9, 10 summarize Pearson's correlation coefficients between different rankings in Ukraine in 2019.

Table 9

\section{Correlation between ranking results of "Top-200 Ukraine", "Contract EIT ${ }^{1}$ Score" and "Scopus" Ratings in 2019}

\begin{tabular}{|c|c|c|c|}
\hline \multirow{2}{*}{$\mathrm{N}$} & \multicolumn{3}{|c|}{ Pearson correlation coefficients $\left(\mathrm{K}_{\text {pear }}\right)$} \\
\hline & Ratings & "Contract IEE Score" & “Scopus" \\
\hline 1 & 2 & 3 & 4 \\
\hline \multicolumn{4}{|c|}{ I. $N=239, K_{c r}=<0.14, p=0.05^{2}$} \\
\hline 1 & “Top-200 Ukraine" & $\mathrm{K}_{\text {pear }}=0.36$ & $\mathrm{~K}_{\text {pear }}=0.74$ \\
\hline 2 & "Contract IEE Score" & & $\mathrm{K}_{\text {pear }}=0.19$ \\
\hline \multicolumn{4}{|c|}{ II. $N=$ Top 20, $K_{c r}=0.444, p=0.05$} \\
\hline 1 & “Top-200 Ukraine” & $\mathrm{K}_{\text {pear }}=0.00$ & $\mathrm{~K}_{\text {pear }}=0.51$ \\
\hline 2 & "Contract IEE Score" & & $\mathrm{K}_{\text {pear }}=0.09$ \\
\hline \multicolumn{4}{|c|}{ III. $N=$ Top 10, $K_{c r}=0.63, p=0.05$} \\
\hline 1 & “Top-200 Ukraine" & $\mathrm{K}_{\text {pear }}=0.22$ & $\mathrm{~K}_{\text {pear }}=0.55$ \\
\hline 2 & "Contract IEE Score" & & $\mathrm{K}_{\text {pear }}=-0.27$ \\
\hline
\end{tabular}

Source: Calculated by authors based on: Konsolidovanyi reitynh..., 2019.

Note: ${ }^{1}$ EIT - External Independent Test.

${ }^{2} \mathrm{~N}$ - Number of HEIs in the sample, $\mathrm{K}_{\mathrm{cr}}$ - the critical value of the correlation coefficient (Horoneskul (compl.), 2009), p - level of significance.

1 External Independent Test (ukr.3HO). 
Of the nine correlation situations reported in Table 9, five do not have a significant correlation (the correlation coefficient value is less than critical), and in three cases the correlation is weak (correlation coefficient less than 0.60 ).

\section{Correlation of rankings of 108 national HEIs by "Consolidated", “Top-200 Ukraine”, “Contract EIT ${ }^{1}$ Score" and "Scopus" Ratings, and Government Benchmarking in 2019}

\begin{tabular}{|c|c|c|c|c|}
\hline \multirow[b]{2}{*}{ № } & \multicolumn{4}{|c|}{ Pearson correlation coefficients $\left(\mathrm{K}_{\text {pear }}\right)$} \\
\hline & Ratings & $\begin{array}{c}\text { "Contract IEE } \\
\text { Score" }\end{array}$ & "Scopus" & $\begin{array}{c}\text { Government } \\
\text { Benchmarking of } \\
\text { national HEIs }\end{array}$ \\
\hline 1 & 2 & 3 & 4 & 5 \\
\hline \multicolumn{5}{|c|}{$I . N=108, K_{c r}=0.19, p=0.05^{2}$} \\
\hline 1 & "Consolidated" & & & $\mathrm{K}_{\text {pear }}=0.31$ \\
\hline 2 & “Top-200 Ukraine" & $\mathrm{K}_{\text {pear }}=0.48$ & $\mathrm{~K}_{\text {pear }}=0.70$ & $\mathrm{~K}_{\text {pear }}=0.26$ \\
\hline 3 & "Contract IEE Score" & & $\mathrm{K}_{\text {pear }}=0.31$ & $\mathrm{~K}_{\text {pear }}=0.34$ \\
\hline 4 & "Scopus" & & & $\mathrm{K}_{\text {pear }}=0.20$ \\
\hline \multicolumn{5}{|c|}{ II. $N=20$ first, $K_{c r}=0.444, p=0.05$} \\
\hline 5 & "Consolidated" & & & $\mathrm{K}_{\text {pear }}=0.444$ \\
\hline 6 & “Top-200 Ukraine" & $\mathrm{K}_{\text {pear }}=0.17$ & $\mathrm{~K}_{\text {pear }}=0.438$ & $\mathrm{~K}_{\text {pear }}=0.21$ \\
\hline 7 & "Contract IEE Score" & & $\mathrm{K}_{\text {pear }}=0.14$ & $\mathrm{~K}_{\text {pear }}=0.51$ \\
\hline 8 & "Scopus" & & & $\mathrm{K}_{\text {pear }}=0.06$ \\
\hline \multicolumn{5}{|c|}{ III. $N=10$ first, $K_{c r}=0.63, p=0.05$} \\
\hline 9 & "Consolidated" & & & $\mathrm{K}_{\text {pear }}=0.23$ \\
\hline 10 & “Top-200 Ukraine” & $\mathrm{K}_{\text {pear }}=0.48$ & $\mathrm{~K}_{\text {pear }}=0.70$ & $\mathrm{~K}_{\text {pear }}=0.14$ \\
\hline 11 & "Contract IEE Score" & & $\mathrm{K}_{\text {pear }}=0.31$ & $\mathrm{~K}_{\text {pear }}=0.04$ \\
\hline 12 & "Scopus" & & & $\mathrm{K}_{\text {pear }}=0.44$ \\
\hline \multicolumn{5}{|c|}{$I V . N=20$ last $, K_{c r}=0.444, p=0.05$} \\
\hline 13 & "Consolidated" & & & $\mathrm{K}_{\text {pear }}=0.04$ \\
\hline \multicolumn{5}{|c|}{$V . N=10$ last $, K_{c r}=0.63, p=0.05$} \\
\hline 14 & "Consolidated" & & & $\mathrm{K}_{\text {pear }}=-0.34$ \\
\hline
\end{tabular}
Kshevetskyi \& Tereshchuk, 2019.

Note: ${ }^{1}$ EIT - External Independent Test.

${ }^{2} \mathrm{~N}$ - Number of HEIs in the sample, $\mathrm{K}_{\mathrm{cr}}$ - the critical value of the correlation coefficient (Horoneskul (compl.), 2009), p - level of significance.

Of the 23 correlation situations listed in Table 10, 14 have no significant correlation (correlation coefficient value less than critical), seven correlation is weak (correlation coefficient less than 0.60).

Thus, from Tables 9, 10, it can be seen that the rating mechanisms currently used to rank HEIs in Ukraine are multi-vectored and unbalanced and do not clearly, objectively, reliably identify university achievements and uniquely and clearly orientate the development teams to the priorities. Therefore, the problem of identifying better and worse, promising and unpromising HEIs nationwide remains unsolved. Without it, it is impossible to effectively implement the government's program of activities in higher education (Pro Prohramu diialnosti..., 2019). 
In addition, the rating and other characteristics of national institutions, their sectoral and regional landscape, indicate the need to introduce, in addition to the general, sectoral and regional versions of the national rating, and a careful selection of its criteria / indicators. For example, among the top 20 national institutions, there are 7 arts and 5 medical HEIs (60\% in total), 4 classical, 2 agrarian, 1 polytechnic and 1 civil defense universities (Nikulina, Kshevetskyi \& Tereshchuk, 2019). Obviously, this does not correspond to the actual distribution of the best national institutions in terms of their profile. In addition, the best national institutions are geographically unevenly located - 11 (55 \%) HEIs in Kyiv and Kharkiv (Nikulina, Kshevetskyi \& Tereshchuk, 2019).

The dominance of accreditation practices and the lack of national rating experience and culture have led to a tendency for formal status (de jure) equalization (by de facto substantial differentiation) of HEIs, their low-level massisation, underestimation of the role and necessity of establishment and support of elite institutions (Lugovyi, Slyusarenko \& Talanova, 2019a, 2019b, 2018a, 2018b; Lugovyi \& Talanova (eds.), 2018). In this regard, it is advisable to use the following model of the place and role of universities in the global, regional, national, subnational, local development to balance and identify mechanisms for evaluating university achievement, awareness of different institutional options, directing and motivating accreditation and ranking in the formulation and implementation of higher education policy and strategy (see Fig. 2).

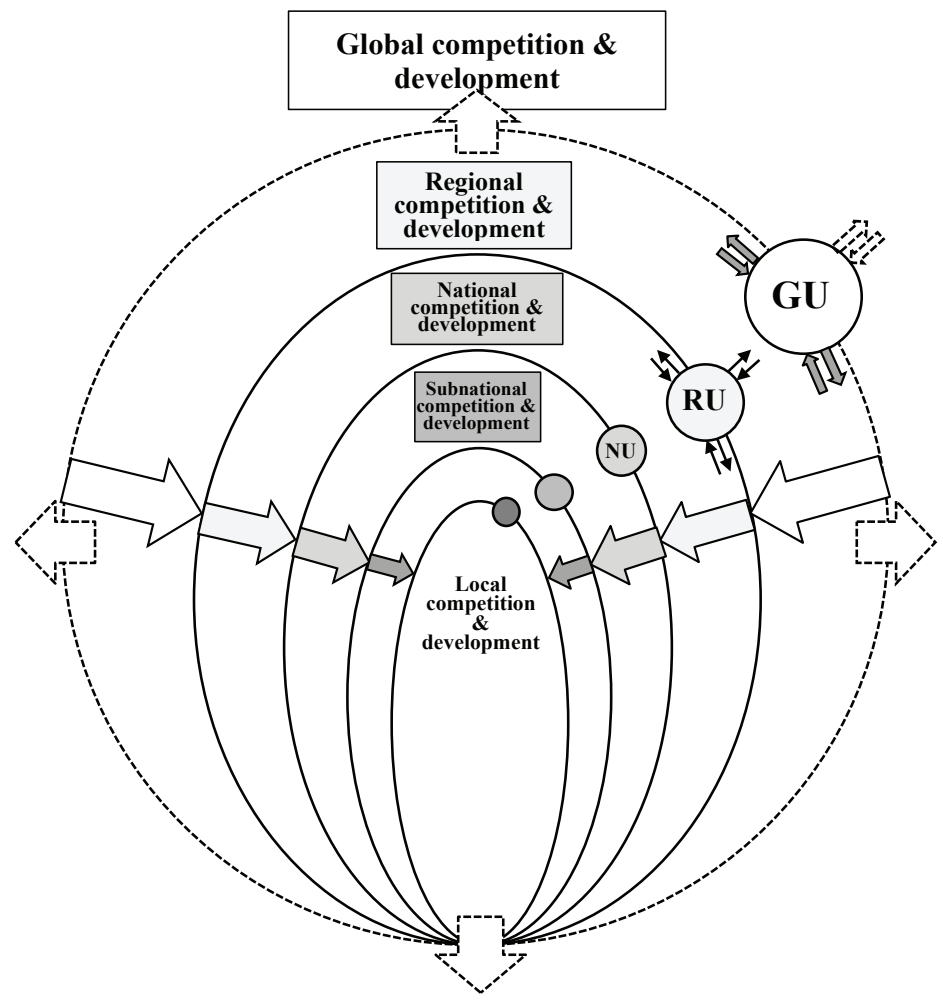

Fig. 2. Model the place and role of universities in global, regional, national, subnational and local development

Source: Designed by authors.

The model (see Fig. 2) with dotted, externally oriented arrows shows the directions of global competitive development at its frontier. The oval / circular lines outline the limits of attained levels of global, regional, national, subnational and local development, which in some cases may coincide (see bottom of Fig. 2). The contextual influence of the higher level of development on the lower level is indicated by internally directed hollow arrows. The circles show the universities that 
operate on the respective cutting edge and perform a dual function. First, they widen the limits of what has been achieved (thanks to R\&D, foresee and produce the future - external arrows), and secondly, extend advanced achievements (through learning and teaching) in modern life internal arrows. Depending on the level at which universities operate, the latter may be global (GU), regional (RU), national (NU), subnational (SNU), local (LU). Universities, by virtue of their status as de jure and de facto, must therefore be differentiated by capacity to serve as centers of global, regional, national, subnational and local growth, in particular through rating. In order to determine university level and status, the global, sectoral and regional rankings should be used, taking into account world practice.

\section{CONLUSIONS}

From the above implies the following conclusions.

1. Higher education in Ukraine is lagging in the globalized world and needs immediate reform in order to increase competitiveness based on the consolidation of HEIs and the concentration of resources in them.

2. Higher education modernization policies and strategies should include the development and implementation of national, sectoral and regional HEIs national rankings as an effective mechanism for assessing, improving and motivating higher education quality.

3. The national ranking of HEIs should be global, sectoral and regional in order to accurately identify higher education growth points at global, regional, national, subnational, local levels.

4. The national rating of HEIs should be based on an objective, transparent and understandable ARWU methodology that is most consistent with the university's mission and innovative type of progress.

\section{REFERENCES}

$8^{\text {th }}$ International Conference on World-Class Universities (WCU-8) (2019). Retrieved 2019 from: http://www.shanghairanking.com/wcu/index.html

Academic Ranking of World Universities (2019a). Retrieved 2019 from: http://www. shanghairanking.com/index.html

Academic Ranking of World Universities (2019b). Retrieved 2019 from: https://drive.google.com/ file/d/17rZNParkJoY70ny6Nq9eRCCCtA2X1aHP/view

Derzhstat Ukrainy (2018). Vyshcha osvita v Ukraini u 2018 rotsi [State Statistics Committee of Ukraine Higher education in Ukraine in 2018]. Retrieved 2019 from: http://www.ukrstat. gov.ua/

Horoneskul, M. (compl.) (2009). Tablytsi funktsii ta krytychnykh tochok rozpodiliv (Rozdily: Teoriia ymovirnostei, Matematychna statystyka, Matematychni metody v psykholohii) [Tables of functions and critical distribution points. Sections: Probability Theory, Mathematical statistics, Mathematical methods in psychology]. Kharkiv: UTsZU. Retrieved 2019 from: http://repositsc.nuczu.edu.ua/bitstream/123456789/1530/1/Tablici.pdf

Informatsiina systema «Konkurs». Vstupna kampaniia 2019 roku [Information system “Competition". Opening Campaign 2019]. Retrieved 2019 from: http://test.vstup.info/2019/ index.html

IREG Observatory on Academic Ranking and Excellence (2019). Retrieved 2019 from: http://iregobservatory.org/en/

Kompas. Rejting ukrainskih vysshih uchebnyh zavedenij po stepeni udovletvorennosti obrazovaniem (2019) [Compass. Rating of Ukrainian higher education institutions by degree of satisfaction with education]. Retrieved 2019 from http://www.yourcompass.org/

Konsolidovanyi reitynh vyshiv Ukrainy 2019 roku [The consolidated rating of Ukrainian universities in 2019]. Retrieved 2019 from: https://osvita.ua/vnz/rating/51741/ 
Kremen, V. (14 veresnia, 2019). Systema pidtrymky innovatsiinoi diialnosti: orhanizatsiine perezavantazhennia? Ukraina ne povynna vtratyty mozhlyvist dlia aktyvizatsii innovatsiinoho vektora rozvytku [Innovation support system: organizational restart? Ukraine should not lose the opportunity to activate an innovative vector of development]. Dzerkalo tyzhnia. Retrieved 2019 from: https://dt.ua/SCIENCE/sistema-pidtrimki-innovaciynoyi-diyalnostiorganizaciyne-perezavantazhennya-323459_.html

Kremen, V., Luhovyi, V., Topuzov, O., Sysoieva, S., Maksymenko, S., Liashenko, O., Nichalo, N. \& Saukh, P. (eds.). (2018). Natsionalnyi osvitno-naukovyi hlosarii [National Educational and Scientific Glossary]. Kyiv: TOV «Konvi Print». Retrieved 2019 from: https://drive.google. com/file/d/1tGrKFIMOY8WIQz9LR_9Co06JVZh3MrZF/view

Lugovyi, V., Orzhel, O., Slyusarenko, O. \& Talanova, Zh. (2018). Education and research duality the determining characteristic of higher education. Education: Modern Discuorses, 1, 71-88. https://doi.org/10.32405/2617-3107-2018-1-8

Lugovyi, V., Slyusarenko, O. \& Talanova, Zh. (2018a). Novi uroky liderstva dlia Ukrainy vid Shankhaiskoho reitynhu 2018 roku [New lessons of leadership for Ukraine from Shanghai ranking 2018]. Pedahohika i psykholohiia. Visn. NAPN Ukrainy, 3, 5-22.

Lugovyi,V.,Slyusarenko, O. \& Talanova,Zh.(2018b). Vid akredytatsii do reitynhu (funktsionuvannia VS rozvytok) [From accreditation to rating (functioning VS development)]. Mizhnarodnyi naukovyi zhurnal «Universytety i liderstvo», 2(6), 3-20. Retrieved 2019 from: https://uljournal.org/index.php/journal/article/view/77/73

Lugovyi, V., Slyusarenko, O. \& Talanova, Zh. (2019a). Realizatsiia doslidnytsko-innovatsiinoho potentsialu universytetiv yak nevidiemnoho skladnyka yikh diialnosti [Realization of the research and innovation capacities of universities as an integral component in their activities]. Nauka ta naukoznavstvo: mizhnarodnyi naukovyi zhurnal, 3 (105), 26-45.

Lugovyi, V., Slyusarenko, O. \& Talanova, Zh. (2019b). Suchasnist i nadsuchasnist - kryterii yakosti vyshchoi osvity [Contemporality and supercontemporality - criteria of quality of higher education]. Mizhnarodnyi naukovyi zhurnal «Universytety i liderstvo», 1(7), 3-25. Retrieved 2019 from: https://ul-journal.org/index.php/journal/article/view/84/80

Lugovyi, V. (ed.), Talanova, Zh. (ed.), Vorobiova, O., Debych M., Lynova I., Orzhel O., ... \& Tryma K. (2018). Analiz providnoho vitchyznianoho ta zarubizhnoho dosvidu shchodo otsiniuvannia yakosti vyshchoi osvity $v$ umovakh yevrointehratsii: analitychni materialy (chastyna I) (preprynt). [Analysis of leading domestic and foreign experience in evaluating the quality of higher education in the context of European integration: analytical materials (part I) (preprint)]. Kyiv: In-t vyshchoi osvity NAPN Ukrainy. Retrieved 2019 from: https://ihed.org. ua/wp-content/uploads/2019/08/Analiz_ocinki_VO_v_umovah_internac_ch1_analit_IVO2018-172p_avtors-kolektiv.pdf

Nikulina O., Kshevetskyi V. \& Tereshchuk V. (2019). Vykonannia kryteriiv nadannia ta pidtverdzhennia statusu natsionalnoho zakladu vyshchoi osvity: Analitychnyi zvit [Meeting the criteria for granting and confirming the status of a national higher education institution: analytical report]. Kyiv : Natsionalne ahentstvo iz zabezpechennia yakosti vyshchoi osvity. Retrieved 2019 from: http://www.euroosvita.net/prog/data/attach/6214/analitichnii_zvit.pdf

OECD (2009). Higher Education to 2030, Volume 2: Globalisation, Executive Summary, OESD Publishing, Paris. Retrieved 2019 from: http://www.oecd.org/education/ceri/44101074.pdf

OECD (2019a). Education at a Glance 2019: OECD Indicators, OECD Publishing, Paris. Retrieved 2019 from: https://read.oecd-ilibrary.org/education/education-at-a-glance-2019_f8d7880den\#page1

OECD (2019b). Main Science and Technology Indicators, Volume 2019 Issue 1, OECD Publishing, Paris. Retrieved 2019 from: https://www.oecd-ilibrary.org/science-and-technology/mainscience-and-technology-indicators/volume-2019/issue-1_msti-v2019-1-en

Pro Prohramu diialnosti Kabinetu Ministriv Ukrainy. Postanova Verkhovnoi Rady Ukrainy vid 4 zhovtnia 2019 r. № 188-IX (2019) [On the Program of Activities of the Cabinet of Ministers 
of Ukraine. Resolution of the Verkhovna Rada of Ukraine]. Holos Ukrainy, 196, 14. Retrieved 2019 from: https://zakon.rada.gov.ua/laws/show/188-20

Pro zatverdzhennia pereliku svitovykh reitynhiv universytetiv dlia vyznachennia osoblyvoi katehorii inozemtsiv ta osib bez hromadianstva, yaki pretenduiut na pratsevlashtuvannia v Ukraini. Rozporiadzhennia Kabinetu Ministriv Ukrainy vid 14 bereznia 2018 r. № 154-r (2018) [On approval of the list of world rankings of universities to determine the special category of foreigners and stateless persons applying for employment in Ukraine. Ordinance of the Cabinet of Ministers of Ukraine]. Retrieved 2019 from: http://zakon2.rada.gov.ua/ laws/show/154-2018-\%D1\%80

Pro zatverdzhennia Polozhennia pro natsionalnu systemu reitynhovoho otsiniuvannia diialnosti vyshchykh navchalnykh zakladiv. Nakaz Ministerstva osvity i nauky, molodi ta sportu Ukrainy vid 20 hrudnia 2011 r. № 1475 (2011) [On approval of the Regulation on the national rating system of higher education institutions. Order of the Ministry of Education and Science, Youth and Sports of Ukraine]. Retrieved 2019 from https://zakon.rada.gov.ua/laws/show/ z0018-12

QS World University Rankings. Retrieved 2019 from: https://www.topuniversities.com/universityrankings/world-university-rankings/2020

Rankings: A Challenge to Higher Education? Retrieved 2019 from: http://ireg-observatory.org/en/ ireg-2019

Reitynh universytetiv za pokaznykamy Scopus 2019 roku [Scopus University Rankings 2019]. Retrieved 2019 from: https://osvita.ua/vnz/rating/64398/

Reitynh universytetiv «TOP-200 Ukraina» 2019 roku [The rating of TOP-200 Ukraine universities in 2019]. Retrieved 2019 from: https://osvita.ua/vnz/rating/64884/

Review of the Education Sector in Ukraine. Moving towards Effectiveness, Equity and Efficiency (RESUME 3). Overview. World Bank Group (2019). Retrieved 2019 from: http://documents. worldbank.org/curated/en/360951568662377063/pdf/Overview.pdf

Salmi, J. (2009). Sozdanie universitetov mirovoho klassa [Establishing world-class universities]. Moskva: «Ves mir».

Shanghai Ranking's Global Ranking of Academic Subjects 2019 Press Release (2019). Retrieved 2019 from: http://www.shanghairanking.com/ShanghaiRankings-Global-Ranking-ofAcademic-Subjects-2019-Press-Release.html

Slyusarenko, O. (2015). Rozvytok naivyshchoho universytetskoho potentsialu $v$ umovakh hlobalizatsii: monohrafiia [Development of the highest university potential in the conditions of globalization: monograph]. Kyiv: Priorytety.

Talanova, Zh. (2010). Doktorska pidhotovka u sviti ta Ukraini: monohrafiia [Doctoral training in the world and Ukraine: monograph]. Kyiv: Milenium.

THE World University Rankings. Retrieved 2019 from: https://www.timeshighereducation.com/ world-university-rankings/2020/world-ranking\#!/page/0/length/25/sort_by/rank/sort_ order/asc/cols/stats

UNDP (2018). Human Development Indices and Indicators: 2018 Statistical Update. Retrieved 2019 from: https://reliefweb.int/sites/reliefweb.int/files/resources/2018_human_development_ statistical_update.pdf

University Quality Idicators: A Critical Assessment: Study. 2015. Retrieved from http://www. europarl.europa.eu/RegData/etudes/STUD/2015/563377/IPOL_STU\%282015\%29563377_ EN.pdf (accessed 14 October, 2019). 